\title{
THE INFLUENCE OF BIOORGANIC PREPARATIONS ON THE PRODUCTIVITY OF CONVENTIONALY GROWN WINTER WHEAT ACTIVATING AND SAVING THE USE OF SYNTHETIC CHEMICALS
}

\begin{abstract}
Vidmantas SPRUOGIS, Institute of Environment and Ecology, Faculty of Forest Sciences and Ecology, Aleksandras Stulginskis University, Studentu str. 11, Academy, Kaunas r., 53361 Lithuania, vidmantas.spruogis@ gmail.com

Anželika DAUTARTÉ, Institute of Environment and Ecology, Faculty of Forest Sciences and Ecology, Aleksandras Stulginskis University, Studentu str. 11, Academy, Kaunas r., 53361 Lithuania, anzelika.dautarte@asu.lt (corresponding author)

Romualdas ZEMECKIS, Aleksandras Stulginskis University, Studentu str. 11, Academy, Kaunas r., 53361 Lithuania., romualdas.zemeckis@asu.lt

Edmundas BARTKEVIČIUS, Faculty of Forest Sciences and Ecology. Aleksandras Stulginskis University, Studentu str. 11, Academy. Kaunas r., 53361 Lithuania, edmundas.bartkevicius@asu.lt

Aida STIKLIENĖ, Institute of Environment and Ecology. Faculty of Forest Sciences and Ecology, Aleksandras Stulginskis University, Studentu str. 11, Academy, Kaunas distr. LT-53361, Lithuania, aida.stikliene@asu.lt

The influence of Raskila bioorganic fertilisers on the productivity of conventional winter wheat 'Olivin', was investigated in order to stimulate and save synthetic herbicide Arrat and fungicide Tango Super for spring spraying. Scheme of treatment: 1 . Control; 2. Winter wheat sprayed (BBCH 20-29) with fertilizer Raskila 31 ha $^{-1} ; 3$. Winter wheat sprayed (BBCH 20-29) with Arrat $0.2 \mathrm{~kg}^{-1}+$ Tango super $1.51 \mathrm{ha}^{-1} ; 4$. Winter wheat sprayed (BBCH 20-29) with Arrat $0.2 \mathrm{~kg} \mathrm{ha}^{-1}+$ Tango super $1.51 \mathrm{ha}^{-1}+$ Raskila $3.01 \mathrm{ha}^{-1} ; 5$. Winter wheat sprayed (BBCH 20-29) with Arrat $0.1 \mathrm{~kg} \mathrm{ha}^{-1}+$ Tango super $0.751 \mathrm{ha}^{-1}+$ Raskila $3.01 \mathrm{ha}^{-1}$. The best result in the period of 2014-2016 was received after application of the following combination in spring: Arrat + Tango super + Raskila. This combination allows to reduce the rate of pesticides in half (50\%), the differences compared to control are significant, statistically reliable. A statistically significant increase in the following winter wheat 'Olivin' quality parameters was found: protein 13.1-14.8\%, gluten 24.3-29.7\%, number of falls $228-292 \mathrm{~s}$, starch 65.7-70.0\%. Application of Raskila fertilizers has raised the grain quality class. The best results were in variants 3 and 4 , where the I class of grain quality was achieved. Combination of Raskila fertilisers and pesticides: herbicide Arrat and fungicide Tango super statistically significantly increased the following winter wheat 'Olivin' characteristics - plant height 101.2-104.2 cm, ear length 6.9-7.1 cm, grain number per ear 28,96-30.02, grain yield 6.71-7.03 tha-1. Application of Raskila fertilizer $1.01 \mathrm{ha}^{-1}$ and herbicide Arrat $0.1 \mathrm{~kg} \mathrm{ha}^{-1} \mathrm{decreased}$ the number of weeds from 62.5 to 57.6 units per $\mathrm{m}^{2}$ and the weed weight decreased from 41.30 to $33.70 \mathrm{~g} \mathrm{~m}^{2}$. Stronger wheat crop overshadowed weeds better. Combination of Raskila and Tango super reduced the prevalence and severity of diseases in winter wheat such as Septoria spp., Pyrenophora tritici-repentis, Erysiphe graminis, powdery rust (Puccinia recondita).
\end{abstract}

Keywords: winter wheat 'Olivin', organic fertilizers Raskila, herbicide Arrat, fungicide Tango super, grain yield, efficiency

\section{INTRODUCTION}

Evaluation of the farming conditions: soil properties, technical and material basis, it is necessary in order to use agricultural land more efficiently and to ensure proper plant nutrition. We exhaust the soil obtaining the maximum yield, at the same time we use its resources and often forget about restoration of soil fertility (Jakiené, Venskutonis, 2008). Production of good quality products without proper nutrients supply and balanced fertilization is difficult goal to achieve. High quantities of nutrients are carried out from the soil together with agricultural production. The deficit of needs to be compensated and rebuilt, otherwise soil will degrade (Žekonienė, 2008). Applying an intensive plant growing technologies, synthetic mineral fertilizers, pesticides and other components are used extensively, and soil properties may deteriorate. We can face with soil aeration problem, leading to accumulation of excess moisture. The soil becomes squeeze, microbiological processes are decreasing. Recently, farmers, gardeners and florists have been increasingly focusing on ecological products. People seek for healthy food and a healthy and beautiful environment. It is very important to maintain a biological balance - undisturbed and productive soil - fertile and healthy plants - good quality food and healthy and beautiful environment (Svirskis, Vilkonis, 2008; Spruogis et al. 2013; Baležentienè et al. 2012; Jakienė et al. 2015).

Biological preparations and bioorganic fertilizers can help to prevent all these problems, to obtain a higher and healthy yield, to maintain a clean and beautiful environment (Минеев, 2008). Bioorganic preparations help to save chemicals and synthetic mineral fertilizers, prevent pests and stop the spread of diseases, these treatments protect the plants from stress and strengthen their immune system, thereby reducing environmental pollution (Brazauskienè, 2004).

Copyright (C) 2017 The Authors. Published by Aleksandras Stulginskis University. This is an open-access article distributed under the terms of the Creative Commons Attribution License (CC-BY 4.0), which permits unrestricted use, distribution, and reproduction in any medium, provided the original author and source are credited. 
Certification organization "Ekoagros" in 2011 certified bioorganic fertilizers Raskila in Lithuania (Gavenauskas et al., 2013; Spruogis et al. 2013; Jakiene et al. 2015). Raskila fertilizers contain all the essential components that are inherent to organic fertilizers. It improves the quality of the soil and increase the amount of humus in it. Raskila fertilizer can be successfully used for mitigating the effects of climate change, environmental pollution, air pollution, soil degradation (Mokslinès..., 2013). Increasing the natural potential of soil through bioorganic fertilizers will balance the quality of the soil, improve the financial indicators and reduce the effects of climate change (Drulis, 2014).

The aim of the research was to investigate the effect of bio-organic fertilizer Raskila on the yield and quality of conventional winter wheat, reducing environmental pollution by activating and saving synthetic herbicide Arrat and fungicide Tango super for spring spraying. Research objectives: 1. to investigate the effect of bioorganic fertiliser Raskila on winter wheat yield and production quality; 2. to analyse the parameters of yield quality, to carry out biometric measurements and chemical analyses; 3 . to assess the weediness and morbidity of the winter wheat.

\section{RESEARCH METHODS}

The research was carried out in 2014 - 2016 at Experimental Station of Aleksandras Stulginskis University. Investigation was carried out according to the following treatment scheme: 1. Control; 2. Winter wheat sprayed (BBCH 20-29) with fertilizer Raskila 31 ha $^{-1}$; 3. Winter wheat sprayed (BBCH 20-29) with Arrat $0.2 \mathrm{~kg} \mathrm{ha}^{-1}+$ Tango super 1.51 $\mathrm{ha}^{-1}$; 4. Winter wheat sprayed (BBCH 20-29) with Arrat $0.2 \mathrm{~kg} \mathrm{ha}^{-1}+$ Tango super $1.51 \mathrm{ha}^{-1}+$ Raskila $3.01 \mathrm{ha}^{-1} ; 5$. Winter wheat sprayed (BBCH 20-29) with Arrat $0.1 \mathrm{~kg} \mathrm{ha}^{-1}+$ Tango super $0.751 \mathrm{ha}^{-1}+$ Raskila $3.01 \mathrm{ha}^{-1}$.

Experiment fields arranged sequentially in four replications. The total size of the plot was $30 \mathrm{~m}^{2}(3 \times 10)$, accounting $-17.6 \mathrm{~m}^{2}(2.2 \times 8)$. The agrochemical properties of the soil were determined before experiment. The analysis was performed using PSCO/ISI Infrared Spectrometer IBM-PC 4250 according to data bank calibrations. The samples were analysed using the following methods (soil $\mathrm{pH}$ - potentiometric method, mobile phosphorus $\mathrm{P}_{2} \mathrm{O}_{5}$ and mobile potassium $\mathrm{K}_{2} \mathrm{O}$ (mg kg-1 soil) - Egner-Rim-Domingo (A-L) method, organic carbon - Thurin method). The agrochemical properties of soil was analysed at the Agrochemical Research Laboratory of the Lithuanian Research Centre for Agriculture and Forestry and at the Soil Laboratory of the State Land Foundation in Kaunas (Spruogis et al. 2013).

The experiments were carried out on a loam in a clay loam (Calc(ar)i-Epihypogleyic Luvisol-LVg-p-w-cc). The water regime was regulated by a closed drainage. The soil was close to neutral and neutral ( $\mathrm{pH}$ 6.8-7.1), amount of phosphorus $171-178 \mathrm{mg} \mathrm{kg}^{-1}$, potassium - 129-141 mg kg-1 , mean amount of humus - 2.26-2.49\%, total nitrogen $0.168-1.172 \%$.

Mineral fertilizers were applied NPK 8-20-30, $300 \mathrm{~kg} \mathrm{ha}^{-1}$. Winter wheat was sown in I decade of September. The average seed rate was $\sim 4 \mathrm{mln} \mathrm{ha}^{-1}$, the sowing depth $-4 \mathrm{~cm}$. Harvested at the end of July. The meteorological conditions were close to the perennial averages during the research.

Bioorganic fertilizers Raskila were developed and produced in Lithuania (UAB Raskilè). Fertilizers are produced from $100 \%$ biohumus and suitable for all plants. Fertilizers contain the whole complex of macro-and trace elements, humic substances, fulvic acids, nitrogen, potassium, phosphorus, phytovitamins and useful soil micro-organisms (Spruogis et al., 2013).

'Olivin' - the variety of winter wheat was created in the United States, breeding company Monsanto. Herbicide Arrat is a broad spectrum systemic herbicide for the elimination of two-headed weeds in winter and summer wheat, spring barley and maize. Fungicide Tango super - as systemic fungicide, used for winter and summer wheat and winter and summer barley, sugar beet protection against fungal diseases.

Winter wheat plants were unrooted and tied in the sheafs before harvesting from two places $\left(0.25 \mathrm{~m}^{2}\right)$ of each experimental plot. The elements of the harvest structure: plant height, ear length, grain number per ear were determined by measurement method. Weediness of the crop was determined at the end of winter wheat vegetation in each variant with two replications in 3-5 different places $\left(0.25 \mathrm{~m}^{2}\right)$, weeds were unrooted and counted, then dried to air dry condition and weighed.

Leaf diseases were recorded in winter wheat $(\mathrm{BBCH} 37)$. The phyto-sanitary state of 60 plants from each variant all vegetable leaves. Visually identified diseases and separately estimated the prevalence of all observed diseases (percentage of damaged leaves) and their intensity (percentage of damaged leaf area) on a scale of 0, 1, 5, 10, 25, 50, $75 \%$, which are standardized by the European Plant Protection Organization methodologies. The severity of the disease (R) is calculated according to the formula: $\mathrm{R}=\Sigma(\mathrm{n} \times \mathrm{b}) / \mathrm{N}$, where $\Sigma(\mathrm{n} \times \mathrm{b})$ is the sum of equally damaged leaves number and the violation value product; $\mathrm{N}$ - number of checked leaves (Žemès ükio..., 2002).

The yield structure elements were determined. The grain was dried up to $14 \%$, estimated the purity and grain yield $t$ $\mathrm{ha}^{-1}$ and the chemical composition was analysed. Proteins and gluten in winter wheat grain were determined according to LST 1522, sedimentation (according to Zeleny) according to LST 1498 by the infrared spectroscopy method (AACC method 39-25: 1998) with a computer analyser Infratec. The number of fall was determined in accordance with LST ISO 3093, the gross weight of grain - according to LST 1578. The chemical composition of grains was analysed at Chemical Research Laboratory and Agrochemical Research Laboratory of the Lithuanian Research Centre for Agriculture and Forestry.

The research data was statistically evaluated by means of dispersion analysis of quantitative attributes using the computer program ANOVA (Tarakanovas, Raudonius, 2003).

\section{RESULTS AND DISCUSSION}

A very important factor is the economic efficiency of the use of pesticides. Application of combination of Raskila fertilizer with herbicide Arrat and fungicide Tango Super on winter wheat 'Olivin' guaranteed the highest income, respectively, from 314.53 to $351.89 € \mathrm{ha}^{-1}$ (Table 1). This combination reduces the use of pesticides by half, which means we save $50 \%$ of pesticides. Economic calculation there plays a crucial role. Estimating economic efficiency we get the 
best results: income from 314.53 to $351.89 € \mathrm{ha}^{-1}$, grain yields $6.89-7.03 \mathrm{t} \mathrm{ha}^{-1}$ and an Extra or I Class best quality grains. Compared to control, the differences are significant, statistically reliable.

Table 1. The effect of bioorganic fertilizer Raskila and synthetic pesticides: herbicide Arrat and fungicide Tango super on winter wheat 'Olivin' productivity and cost-effectiveness

\begin{tabular}{|c|c|c|c|c|c|c|}
\hline Treatment & $\begin{array}{l}\text { Grain } \\
\text { yield } \\
\mathrm{t} \mathrm{ha}^{-1}\end{array}$ & $\begin{array}{c}\text { Grain } \\
\text { yield } \\
\text { increase } \\
\mathrm{t} \mathrm{ha}^{-1}\end{array}$ & $\begin{array}{l}\text { Grain yield } \\
\text { increase } \\
\text { value } \\
€ \text { ha }^{-1}\end{array}$ & $\begin{array}{c}\text { Premium for } \\
\text { the qualitative } \\
\text { class of grain } \\
€\end{array}$ & $\begin{array}{l}\text { Cost of } \\
\text { Raskila and } \\
\text { pesticides } \\
€ \text { ha }^{-1}\end{array}$ & $\begin{array}{l}\text { Income } \\
€ \text { ha }^{-1}\end{array}$ \\
\hline 1. Control & 5.10 & - & - & - & - & - \\
\hline $\begin{array}{l}\text { 2. Winter wheat sprayed (BBCH 20-29) with } \\
\text { fertilizer Raskila } 3 \mathrm{l} \mathrm{ha}^{-1}\end{array}$ & 6.78 & 1.68 & 301.49 & +17.38 & 5.79 & 313.08 \\
\hline $\begin{array}{l}\text { 3. Winter wheat sprayed (BBCH 20-29) with } \\
\text { Arrat } 0.2 \mathrm{~kg} \mathrm{ha}^{-1}+\text { Tango super } 1.51 \mathrm{ha}^{-1} \text {; }\end{array}$ & 6.71 & 1.61 & 289.04 & +11.58 & 23.17 & 277.46 \\
\hline $\begin{array}{l}\text { 4. Winter wheat sprayed (BBCH 20-29) with } \\
\text { Arrat } 0.2 \mathrm{~kg} \mathrm{ha}^{-1}+\text { Tango super } 1.51 \mathrm{ha}^{-} \\
{ }^{1}+\text { Raskila } 3.01 \mathrm{ha}^{-1}\end{array}$ & 6.89 & 1.79 & 331.90 & +17.38 & 34.75 & 314.53 \\
\hline $\begin{array}{l}\text { 5. Winter wheat sprayed (BBCH 20-29) with } \\
\text { Arrat } 0.1 \mathrm{~kg} \mathrm{ha}^{-1}+\text { Tango super } 0.751 \mathrm{ha}^{-} \\
{ }^{1}+\text { Raskila } 3.01 \mathrm{ha}^{-1}\end{array}$ & 7.03 & 1.93 & 357.68 & +17.38 & 23.17 & 351.89 \\
\hline 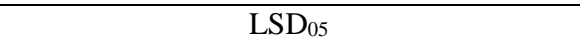 & 0.78 & & & & & \\
\hline
\end{tabular}

Application of combination of Raskila fertilizer with herbicide Arrat and fungicide Tango Super significantly increased the following winter wheat 'Olivin' grain quality parameters: proteins by 13.1-14.8 \%, gluten - 24.3-29.7\%, and the number of falls by 228-292 s, starch by $65.7-70.0 \%$. Raskila fertilizers have raised the grain quality class. The best results were in the 2 nd 4 th and 5 th variants, where I grain quality class was achieved (Table 2).

Table 2. The effect of bioorganic fertilizer Raskila and synthetic pesticides: herbicide Arrat and fungicide Tango super on winter wheat 'Olivin' grain quality

\begin{tabular}{|c|c|c|c|c|c|c|}
\hline Treatment & $\begin{array}{c}\text { Proteins } \\
\%\end{array}$ & $\begin{array}{l}\text { Gluten } \\
\%\end{array}$ & $\begin{array}{l}\text { Weight } \\
\text { of } \\
\text { hectolitre } \\
\mathrm{kg} \mathrm{hl}^{-1}\end{array}$ & $\begin{array}{l}\text { Falling } \\
\text { number } \\
\text { s }\end{array}$ & $\begin{array}{l}\text { Starch } \\
\%\end{array}$ & $\begin{array}{l}\text { Quality class } \\
\text { of grain }\end{array}$ \\
\hline 1. Control & 11.0 & 20.2 & 70 & 203 & 63.9 & 3 \\
\hline $\begin{array}{l}\text { 2. Winter wheat sprayed (BBCH 20-29) } \\
\text { with fertilizer Raskila } 31 \mathrm{ha}^{-1}\end{array}$ & 14.2 & 26.0 & 76 & 235 & 68.0 & 1 \\
\hline $\begin{array}{l}\text { 3. Winter wheat sprayed (BBCH 20-29) } \\
\text { with Arrat } 0.2 \mathrm{~kg} \mathrm{ha}^{-1}+\text { Tango super } 1.51 \\
\mathrm{ha}^{-1} \text {; }\end{array}$ & 13.1 & 24.3 & 74 & 228 & 65.7 & 2 \\
\hline $\begin{array}{l}\text { 4. Winter wheat sprayed (BBCH 20-29) } \\
\text { with Arrat } 0.2 \mathrm{~kg} \mathrm{ha}^{-1}+\text { Tango super } 1.51 \\
\text { ha }^{-1}+\text { Raskila } 3.01 \mathrm{ha}^{-1}\end{array}$ & 14.7 & 29.1 & 78 & 284 & 70.0 & 1 \\
\hline $\begin{array}{l}\text { 5. Winter wheat sprayed (BBCH 20-29) } \\
\text { with Arrat } 0.1 \mathrm{~kg} \mathrm{ha}^{-1}+\text { Tango super } 0.751 \\
\text { ha }^{-1}+\text { Raskila } 3.01 \mathrm{ha}^{-1}\end{array}$ & 14.8 & 29.7 & 79 & 292 & 70.0 & 1 \\
\hline $\mathrm{LSD}_{05}$ & 0.7 & 1.7 & 2 & 51 & 0.7 & \\
\hline
\end{tabular}

Raskila fertilizers and pesticides significantly increased biometric parameters of winter wheat 'Olivin': the plant height $-101.22-104.23 \mathrm{~cm}$, the ear length was $6.86-7.14 \mathrm{~cm}$, number of grain per ear 28.96-30.02, grain yield 6.71-7.03 $\mathrm{t} \mathrm{ha}^{-1}$ (Table 3 ). The assessment of the quality of grain and calculation of economic efficiency proved the most rational treatment combination: herbicide Arrat $0.1 \mathrm{~kg} \mathrm{ha}^{-1}$, fungicide Tango super $0.751 \mathrm{ha}^{-1}$ and Raskila fertilizers $3.01 \mathrm{ha}^{-1}$.

Table 3. The effect of bioorganic fertilizer Raskila and synthetic pesticides: herbicide Arrat and fungicide Tango super on winter wheat 'Olivin' yield and biometric parameters

\begin{tabular}{|c|c|c|c|c|c|}
\hline Treatment & $\begin{array}{c}\text { Plant } \\
\text { height } \mathrm{cm}\end{array}$ & $\begin{array}{l}\text { Ear length } \\
\mathrm{cm}\end{array}$ & $\begin{array}{l}\text { Number of } \\
\text { grain per ear }\end{array}$ & $\begin{array}{c}\text { Grain yield } \\
\mathrm{t} \mathrm{ha}^{-1}\end{array}$ & $\begin{array}{l}\text { Grain yield } \\
\text { increase \% }\end{array}$ \\
\hline 1. Control & 88.76 & 5.62 & 24.88 & 5.10 & 100 \\
\hline $\begin{array}{l}\text { 2. Winter wheat sprayed (BBCH 20-29) with } \\
\text { fertilizer Raskila } 31 \mathrm{ha}^{-1}\end{array}$ & 102.00 & 6.92 & 29.88 & 6.78 & 132.94 \\
\hline $\begin{array}{l}\text { 3. Winter wheat sprayed (BBCH 20-29) with } \\
\text { Arrat } 0.2 \mathrm{~kg} \mathrm{ha}^{-1}+\text { Tango super } 1.51 \mathrm{ha}^{-1}\end{array}$ & 101.22 & 6.86 & 28.96 & 6.71 & 131.57 \\
\hline $\begin{array}{l}\text { 4. Winter wheat sprayed (BBCH 20-29) with } \\
\text { Arrat } 0.2 \mathrm{~kg} \mathrm{ha}^{-1}+\text { Tango super } 1.51 \mathrm{ha}^{-} \\
{ }^{1}+\text { Raskila } 3.01 \mathrm{ha}^{-1}\end{array}$ & 103.45 & 7.01 & 29.48 & 6.89 & 135.10 \\
\hline $\begin{array}{l}\text { 5. Winter wheat sprayed (BBCH 20-29) with } \\
\text { Arrat } 0.1 \mathrm{~kg} \mathrm{ha}^{-1}+\text { Tango super } 0.751 \mathrm{ha}^{-} \\
{ }^{1}+\text { Raskila } 3.0 \mathrm{l} \mathrm{ha}^{-1}\end{array}$ & 104.23 & 7.14 & 30.02 & 7.03 & 137.84 \\
\hline LSD05 & 10.79 & 0.79 & 0.47 & 0.78 & \\
\hline
\end{tabular}


An analysis of crop morbidity and weedness data allows broader assessment of applied treatments interaction. The research data shows, that winter wheat receiving different pesticides rates, and especially in combination with Raskila fertilizers, strengthened and were able themselves to control weeds. The number of weeds decreased from 62.5 to 57.6 units per $\mathrm{m} 2$ and weed mass - from 41.30 to $33.70 \mathrm{~g} \mathrm{~m}^{-2}$ (Table 4).

Table 4. The effect of bioorganic fertilizer Raskila and synthetic pesticides: herbicide Arrat and fungicide Tango super on weedness

\begin{tabular}{|c|c|c|}
\hline Treatment & $\begin{array}{l}\text { Number of weeds } \\
\mathrm{m}^{-2}\end{array}$ & $\begin{array}{l}\text { Weeds mass } \\
\mathrm{g} \mathrm{m}^{-2}\end{array}$ \\
\hline 1. Control & 105.1 & 73.93 \\
\hline 2. Winter wheat sprayed (BBCH 20-29) with fertilizer Raskila 31 ha $^{-1}$ & 101.6 & 73.55 \\
\hline $\begin{array}{l}\text { 3. Winter wheat sprayed (BBCH 20-29) with Arrat } 0.2 \mathrm{~kg} \mathrm{ha}^{-1}+\text { Tango super } 1.51 \\
\mathrm{ha}^{-1}\end{array}$ & 62.5 & 41.3 \\
\hline $\begin{array}{l}\text { 4. Winter wheat sprayed (BBCH 20-29) with Arrat } 0.2 \mathrm{~kg} \mathrm{ha}^{-1}+\text { Tango super } 1.51 \\
\text { ha }^{-1}+\text { Raskila } 3.01 \mathrm{ha}^{-1}\end{array}$ & 57.6 & 36.60 \\
\hline $\begin{array}{l}\text { 5. Winter wheat sprayed (BBCH 20-29) with Arrat } 0.1 \mathrm{~kg} \mathrm{ha}^{-1}+\text { Tango super } 0.75 \\
1 \mathrm{ha}^{-1}+\text { Raskila } 3.01 \mathrm{ha}^{-1}\end{array}$ & 58.4 & 33.7 \\
\hline LSD05 & 13.45 & 11.08 \\
\hline
\end{tabular}

Analysing winter wheat morbidity data, it is evident that Raskila fertilizers and pesticides have reduced the occurrence and intensity of diseases such as Septoria spp., Pyrenophora tritici-repentis, Erysiphe graminis, Puccinia recondita in different stages of their growth (Table 5).

Table 5. The effect of bioorganic fertilizer Raskila and synthetic pesticides: herbicide Arrat and fungicide Tango super on winter wheat morbidity (BBCH-37)

\begin{tabular}{|c|c|c|c|c|c|c|c|c|}
\hline \multirow{2}{*}{ Treatment } & \multicolumn{2}{|c|}{ Septoria spp. } & \multicolumn{2}{|c|}{$\begin{array}{c}\text { Pyrenophora } \\
\text { tritici-repentis }\end{array}$} & \multicolumn{2}{|c|}{ Erysiphe graminis } & \multicolumn{2}{|c|}{ Puccinia recondita } \\
\hline & $\begin{array}{c}\text { Occurrence } \\
\%\end{array}$ & $\begin{array}{c}\text { Intensity } \\
\%\end{array}$ & $\begin{array}{c}\text { Occurrence } \\
\%\end{array}$ & $\begin{array}{c}\text { Intensity } \\
\%\end{array}$ & $\begin{array}{c}\text { Occurrence } \\
\%\end{array}$ & $\begin{array}{c}\text { Intensity } \\
\%\end{array}$ & $\begin{array}{c}\text { Occurrence } \\
\%\end{array}$ & $\begin{array}{c}\text { Intensity } \\
\%\end{array}$ \\
\hline 1. Control & 36.73 & 4.82 & 9.88 & 1.45 & 1.11 & 0.1 & 10.56 & 1.83 \\
\hline $\begin{array}{l}\text { 2. Winter wheat sprayed } \\
\text { (BBCH 20-29) with fertilizer } \\
\text { Raskila } 31 \mathrm{ha}^{-1}\end{array}$ & 36.00 & 4.75 & 9.54 & 0.98 & 1.11 & 0.01 & 2.65 & 0.24 \\
\hline $\begin{array}{l}\text { 3. Winter wheat sprayed } \\
(\mathrm{BBCH} 20-29) \text { with Arrat } 0.2 \\
\mathrm{~kg} \mathrm{ha}^{-1}+\text { Tango super } 1.5 \mathrm{ha}^{-1}\end{array}$ & 35.86 & 4.62 & 9.26 & 0.55 & 1.11 & 0.01 & 2.22 & 0.11 \\
\hline $\begin{array}{l}\text { 4. Winter wheat sprayed } \\
(\mathrm{BBCH} 20-29) \text { with Arrat } 0.2 \\
\mathrm{~kg} \mathrm{ha}^{-1}+\text { Tango super } 1.51 \mathrm{ha}^{-} \\
{ }^{+}+\text {Raskila } 3.01 \mathrm{ha}^{-1}\end{array}$ & 35.80 & 4.70 & 6.67 & 0.50 & 0 & 0 & 2.59 & 0.37 \\
\hline $\begin{array}{l}\text { 5. Winter wheat sprayed } \\
\left(\mathrm{BBCH}^{20-29)} \text { with Arrat } 0.1\right. \\
\mathrm{kg} \mathrm{ha}^{-1}+\text { Tango super } 0.751 \mathrm{ha}^{-} \\
{ }^{1}+{\text { Raskila } 3.01 \mathrm{ha}^{-1}}\end{array}$ & 32.84 & 4.35 & 5.93 & 0.56 & 0 & 0 & 3.33 & 0.5 \\
\hline
\end{tabular}

\section{CONCLUSIONS}

1. The best economic efficiency growing conventional winter wheat was got applying together bioorganic fertilizer Raskila $\left(3.01 \mathrm{ha}^{-1}\right)$, herbicide Arrat and fungicide Tango super in spring. The income was $314.53-351.89 € \mathrm{ha}^{-1}$, grain yield 6.89-7.03 $\mathrm{t} \mathrm{ha}^{-1}$ and grain the I Class of quality. This combination reduces necessity of pesticides in half $(50 \%)$. The differences are significant, statistically reliable compared to control.

2. Application of combination of Raskila fertilizer with herbicide Arrat and fungicide Tango Super significantly increased the following winter wheat 'Olivin' grain quality parameters: proteins by $13.1-14.8 \%$, gluten - 24.3$29.7 \%$, and the number of falls by $228-292 \mathrm{~s}$, starch by $65.7-70.0 \%$. Raskila fertilizers have raised the grain quality class.

3. Raskila fertilizers and pesticides: herbicide Arrat and fungicide Tango super significantly increased biometric parameters of winter wheat 'Olivin': the plant height $-101.22-104.23 \mathrm{~cm}$, the length of the ear was $6.86-7.14 \mathrm{~cm}$, number of seeds per ear 28,96-30,02 pcs, grain yield 6,71-7,03 $\mathrm{t} \mathrm{ha}^{-1}$.

4. Treatment with bioorganic fertilizers Raskila $\left(3.01 \mathrm{ha}^{-1}\right)$ and herbicide Arrat $\left(0.1-0.2 \mathrm{~kg} \mathrm{ha}^{-1}\right)$ decreased number of weeds from 62.5 to 57.6 units per $\mathrm{m}^{2}$ and weed mass - from 41.30 to $33.70 \mathrm{~g} \mathrm{~m}^{-2}$. Winter wheat strengthened and were able themselves to control weeds

5. Treatment with bioorganic fertilizers Raskila $\left(3.01 \mathrm{ha}^{-1}\right)$ and fungicide Tango super $\left(0.75-1.5 \mathrm{~kg} \mathrm{ha}^{-1}\right)$ reduced the occurrence and intensity of diseases such as Septoria spp., Pyrenophora tritici-repentis, Erysiphe graminis, Puccinia recondita in different stages of winter wheat growth. 


\section{REFERENCES}

1. Baležentienė L., Spruogis V., Snieškienė V., Stankevičienė A. 2012. Effects of liquid humic fertilizer on changes in biometric indices of winter wheat during autumn acclimation. Journal of Food. Agriculture \& Environment, Vol. 10. No. 3\&4. pp. 463-467.

2. Brazauskienė D. M. 2004. Agroekologija ir chemija. Kaunas. 208 p. [In Lithunian]

3. Drulis P. 2014. Inovatyvūs produktai - biologinès trąšos. Mano ūkis. Available at http://www.manoukis.lt/naujienos/ukis/18395inovatyvus-produktai-biologines-trasos [In Lithunian]

4. Gavenauskas A., Spruogis V., Dautartė A., Bartkevičius E. 2013.The Influence of Organic Fertilizer "Bioplant Flora" on Winter Wheat Biometric Indicators and Productivity. Rural development 2013: the sixth international scientific conference. Akademija: Aleksandras Stulginskis University, Vol. 6, Book 2. p. 89-93.

5. Jakienė E., Spruogis V., Romaneckas K., Dautartė A., Avižienytė D. 2015. The bio-organic nano fertilizer improves sugar beet photosynthesis process and productivity. Žemdirbystè = Agriculture, Vol. 102, No. 2. pp. 141-146.

6. Jakienė, E., Venskutonis, V., Augimo reguliatoriai augalininkysteje. Akademija, 80 p.

7. Mokslinio tiriamojo projekto Nr. M-06-29/13 „Lietuvoje gaminamų naujų biologiškai aktyvių trąšų RASKILA ir bičių produktų perdirbimo atliekų panaudojimo augalų tręšimui taikomieji tyrimai ekologiniuose ir chemizuotuose ūkiuose“ 2013 m. baigiamoji ataskaita. [In Lithunian]

8. Spruogis V., Dautartė A., Gavenauskas A., Bartkevičius E. 2013. The Influence of Universal Bioorganic Nano Fertilizer NAGRO on Spring Barley Crop Productivity. Rural development 2013: the sixth international scientific conference. Akademija: Aleksandras Stulginskis University. Vol. 6, Book 3, pp. 441-445.

9. Svirskis A., Vilkonis K.K. 2008. Augalu sistematika ir ekologijos pagrindai. Šiauliai. 216 p. [In Lithunian]

10. Tarakanovas P., Raudonius S. 2003. Agronominių tyrimų duomenų statistinė analizė taikant kompiuterines programas ANOVA. STAT. SPLIT-PLOT iš paketo SELEKCIJA ir IRRISTAT. Akademija, 57 p. [In Lithunian]

11. Žekonienė V. 2008. Augalų kaitos pagrindai. Kaunas. 150 p. [In Lithunian]

12. Žemès ūkio augalų kenkejjai, ligos ir jų apskaita. 2002. Akademija (Kėdainių r.). 345 p. [In Lithunian]

13. Минеев В.Г., Павлов А.Н. 2008. Агрохимические основы повышения качества озимой пшеницы. М. Колос. 286. [In Russian] 